\title{
Pengaturan Peraturan Daerah Kabupaten Solok Nomor 6 Tahun 2002 Tentang Berpakaian Muslim Dan Muslimah Dalam Perspektif Hukum Ketatanegaraan Indonesia
}

\author{
Oleh: Ari Wibowo \\ Mahasiswa FH UII \\ e-mail: arie_smart01@yahoo.com
}

\begin{abstract}
The issuance of various shariah based ordinances in many provinces and residences across the country, such as those which have been issued in Solok Residence, namely ordinance no. 6 of 2002 on Moslem Attire, may lead to the violence against the rights of the religion's adherents to be protected by the state in serving religious tenets. If such kind ordinances let to be issued more, may lead to the disintegrate of the country.
\end{abstract}

Keywords: Perda Kabupaten Solok, Hukum Ketatanegaraan Indonesia

\section{Pendahuluan}

Keberadaan Otonomi Daerah di Negara Republik Indonesia telah menjadi konsensus nasional. Pemikiran perlunya keberaan Otonomi Daerah di Indonesia telah dilontarkan oleh para pembentuk UUD 1945 tanpa ada kontra argumentasi. Pengadaan Otonomi Daerah bukan hanya sekedar untuk menjamin efisiensi dan efektivitas penyelenggaraan pemerintahan saja, atau menampung kenyataan wilayah negara Indonesia yang luas, penduduknya banyak, dan berpulau pulau yang terpisah pisah, namun Otonomi Daerah merupakan dasar memperluas pelaksanaan demokrasi dan instrumen dalam rangka mewujudkan kemakmuran dan kesejahteraan rakyat, bahkan Bagir Manan pernah mengatakan bahwa Otonomi Daerah merupakan salah satu sendi ketatanegaraan Republik Indonesia. ${ }^{1}$

${ }^{1}$ Sudi fahmi. 2007. Penyelesaian Konflik Pengaturan Perundang Undangan pada Era Otonomi Daerah; Studi Kasus Bidang Kehutanan. Dalam Ni' matul Huda dan Sri 
Amandemen UUD 1945 telah memberikan sejumlah paradigma baru dalam penyelenggaraan Pemerintahan Daerah. Pasal 18 tentang Pemerintahan Daerah pasca Amandemen UUD 1945 telah mengalami perubahan yang signifikan dibanding sebelumnya, karena yang semula ketentuan pasal 18 terdiri dari 1 pasal saja, pasca Amandemen UUD 1945 bertambah menjadi 3 pasal. Pasal 18 terdiri dari 7 ayat, pasal 18A terdiri dari 2 ayat, dan pasal 18B juga terdiri atas 2 ayat. Berdasarkan perubahan tersebut, maka gagasan Otomi Daerah tetap dipertahankan di dalam UUD 1945 yang sudah mengalami amandemen selama empat kali, dan dengan demikian pula tidak bisa dielakkan lagi bahwa pelaksanaan Otonomi Daerah memiliki payung hukum yang kuat karena merupakan amanah konstitusi.

Sejak disahkan Undang Undang No. 22 Tahun 1999 tentang Pemerintahan Daerah² sebagai pelaksanaan dari otonomi daerah, Pemerintah Daerah memiliki kewenangan yang luas dalam pengelolaan di daerahnya. Dengan adanya kewenangan yang luas inilah, maka implementasi Peraturan Daerah (Perda) Syari'at marak terjadi di beberapa tempat di Indonesia. Perda inilah yang kemudian dikenal dengan Perda Syari'at. Sampai November tahun 2007, sekurang-kurangnya 26 daerah tingkat I dan tingkat II yang telah memiliki dan menerapkan Perda Syari'at ini, yaitu Kab. Bulukumba, Kab. Maros, Kab. Gowa, Kab. Enrekang, Sinjai, Gorontalo (Sulawesi Selatan), Banten, Kota Tangerang, Kepulauan Riau, Kota Cianjur, Kab. Cianjur, Tasikmalaya, Garut, Indramayu (Jawa Barat), Pamekasan, Kota Padang, Padang Pariaman, Solok, Pasaman Barat, Limapuluh Kota (Sumatera Barat), Bengkulu, Kota Palembang (Sumatera Selatan), Jember dan Mandailing Natal (Madina). ${ }^{3}$ Bukan hanya dalam bentuk Perda baik di tingkat propinsi maupun kabupaten/ kota, tetapi juga dalam bentuk Rencana Strategis (Renstra), Surat Keputusan, Instruksi atau Edaran Bupati dan lainnya yang isinya mengatur penerapan Syari'at Islam dengan bentuk yang beragam, dari yang mengatur persoalan Sholat Jum'at khusyuk, keharusan bisa baca tulis al-Qur'an, berbusana Muslim,

Hastuti Puspita Sari (ed.), Kontribusi Pemikiran untuk 50 tahun Prof. Dr. Moh Mahfud MD., SH. (Retrospeksi Terhadap Masalah Hukum dan Kenegaraan), Yogyakarta: FH UII Press, 2007, Hlm. 163.

${ }^{2}$ Sekarang sudah diganti dengan Undang Undang No. 32 Tahun 2004 Tentang Pemerintahan Daerah.

${ }^{3}$ Ramli Abdul Wahid, Urgensi Peraturan Daerah Syariah, Dalam Waspada Online, Jumat, 02 November 2007 21:31 WIB. 
pemberdayaan Zakat, Infak, dan Sedekah, Pencegahan dan pemberantasan maksiat, penertiban minuman keras dan pelacuran, hingga penerapan sebagian hukum pidana Islam (kendati yang disebut terakhir hanya terjadi di Aceh), seperti hukum cambuk bagi penjudi dan pelaku khalwat (laki-laki dan wanita dewasa berdua-duaan di tempat sepi). ${ }^{4}$

Implementasi beberapa Perda Syari'at banyak menimbulkan kontroversi, bukan saja dari kalangan non-muslim yang menganggapnya sebagai perda diskriminatif, namun dari kalangan muslim pun serta para ahli hukum tatanegara tidak jarang yang menolak pemberlakuan Perda Syari'at, karena Perda Syari'at dianggap tidak sesuai dengan hukum ketatanegaraan Indonesia. Di saat terjadi banyaknya pihak yang menentang implementasi Perda Syari'at, beberapa waktu yang lalu wakil presiden RI mengatakan bahwa perda perda yang oleh banyak pihak diklaim sebagai Perda Syari' at tidak semuanya dapat dikualifikasikan sebagai perda Syari'at karena tidak semuanya bersumber dari syari'at, misalnya saja Perda Pelacuran di Tangerang dan Perda tentang Minuman Keras. Menurutnya kedua perda tersebut merupakan hukum umum, bukan syari'at. ${ }^{5}$

Tidak mudah memang untuk mengklaim suatu perda sebagai perda syari'at, karena tidak semua perda yang dianggap perda syari'at oleh masyarakat secara eksplisit mencantumkan bahwa perda tersebut bersumber dari syari'at, walaupun ada juga beberapa perda yang isinya secara eksplisit mengindikasikan bersumber dari syari'at Islam, misalnya Peraturan Daerah Kabupaten Solok Nomor 6 Tahun 2002 tentang Berpakaian Muslim dan Muslimah di Kabupaten Solok. Di antara pasal pasalnya mencantumkan secara eksplisit bahwa perda ini didasarkan pada syari' at Islam, yaitu:

1. Dengan Rahmat Allah Subhanahu Wata'ala (judul Perda).

2. Bahwa sebagai salah satu perwujudan dari pelaksanaan ajaran Agarna Islam adalah tercerinin dari pakaiannya dalam kehidupan sehari-hari (konsideran huruf b).

3. Bahwa menutup aurat didalam Islam hukumnya adalah wajib, baik didalam ibadah yang bersifat mahdah maupun yang bersifat ammah (konsideran huruf c).

${ }^{4}$ http:/ /ayok.wordpress.com/2007/01/04/selamatkan-indonesia-dengansyariah-menuju-indonesia-lebih-baik/ yang direkam pada 6 Des 2007 14:51:25 GMT.

${ }^{5} \mathrm{http}: / /$ www.bainfokomsumut.go.id/open.php?id=62\&db=gis yang direkam pada 8 Sep 2007 04:02:57 GMT. 
4. Dan masih banyak pasal pasal lain yang menunjukkan bahwa perda ini adalah perda Syari'at. ${ }^{6}$

Atas pertimbangan inilah, maka hanya Peraturan Daerah Kabupaten Solok Nomor 6 Tahun 2002 tentang Berpakaian Muslim dan Muslimah di Kabupaten Solok ini yang dikaji dalam tulisan ini karena pasal pasal dalam perda ini mengindikasikan bahwa perda ini merupakan perda syari'at yang bersumber dari syari'at Islam. Perlunya pengkajian terhadap salah satu perda syari'at saja karena untuk melakukan penelitian terhadap perda syari'at secara umum akan membutuhkan waktu yang panjang karena harus dilihat dulu perda dimaksud one by one, case by case, content by content, tidak bisa main pukul rata.

Berdasarkan uraian di atas, masalah yang menarik untuk dikaji lebih jauh adalah bahwa di satu sisi dengan adanya Otonomi Daerah, daerah diberi wewenang yang luas untuk mengelola daerahnya masing masing, namun di lain sisi, Perda Syari'at yang diimplementasikan di beberapa daerah dianggap tidak bersesuaian dengan hukum ketatanegaraan Indonesia dan diskriminatif, melanggar Hak Asasi Manusia, padahal perlindungan terhadap HAM merupakan amanah konstitusi yang harus ditegakkan.

\section{Stufen Theory (Teori Berjenjang)}

Konsep pemberlakuan hukum dalam hukum ketatanegaraan Indonesia menganut Teori Berjenjang (Stufen Theory) dari Hans Kelsen. Teori tersebut mengandung ajaran ajaran sebagai berikut:

1. Dasar berlakunya dan legalitas suatu norma terletak pada norma yang yang ada di atasnya (dari bawah ke atas), atau

2. Suatu norma yang menjadi dasar berlakunya dan legalitas norma yang ada di bawahnya (dari atas ke bawah)

3. Secara acak, diambil dua norma saja, bisa dari bawah bisa dari atas atau dari atas ke bawah seperti pada uraian pada huruf a dan b di atas. ${ }^{7}$

Dalam praktek di Indonesia, stufen theory dapat digambarkan sebagai berikut:8

${ }^{6}$ Selengkapnya lihat Peraturan Daerah Kabupaten Solok Nomor 6 Tahun 2002 Tentang Berpakaian Muslim dan Muslimah di Kabupaten Solok.

${ }^{7}$ Bachsan Mustafa, Sistem Hukum Indonesia Terpadu. Bandung: PT Citra Aditya Bakti, 2000, Hlm. 117.

${ }^{8}$ Ibid. 


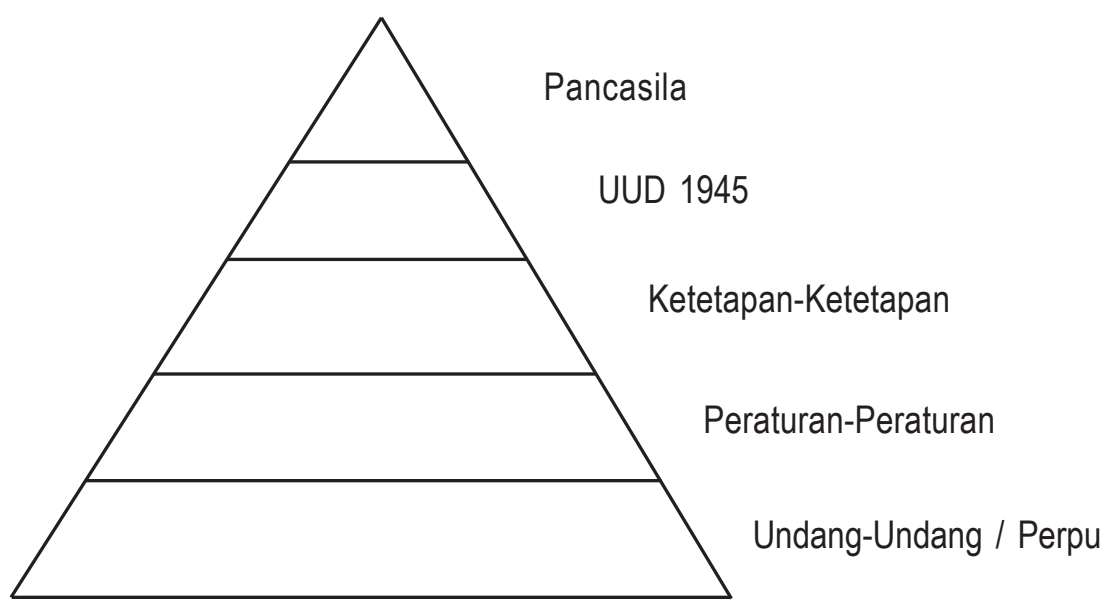

Gambar 1.

Teori berjenjang ini kemudian menimbulkan asas hukum lex supperiori derogat lex inferiori (hukum yang ada di bawah tidak boleh bertentangan dengan hukum yang di atasnya). Berdasarkan teori ini, maka peraturan perundang undangan yang berada di bawah, jika bertentangan dengan peraturan perundang undangan yang ada di atasnya, ia dapat dibatalkan demi hukum.

Hierarki Peraturan perundang undangan di Indonesia secara terperinci meliputi:

1. Undang-Undang Dasar Negara Republik Indonesia Tahun 1945;

2. Undang-Undang/ Peraturan Pemerintah Pengganti Undang-Undang;

3. Peraturan Pemerintah;

4. Peraturan Presiden;

5. Peraturan Daerah. ${ }^{9}$

Dengan hierarki di atas nampak jelas bahwa undang undang No. 10 tahun 2004 menetapkan jenis jenis peraturan perundang undangan dengan tidak memasukkan Tap MPR sebagai peraturan perundang undangan, dan Peraturan Daerah merupakan peraturan perundang undangan yang paling bawah, sehingga keberadaannya tidak boleh bertentangan dengan peraturan perundang undangan yang berada di atasnya.

Meskipun Pancasila tidak disebutkan di dalam hierarki peraturan perundang undangan berdasarkan UU No. 10 tahun 2004, namun

\footnotetext{
${ }^{9}$ Undang Undang No. 10 tahun 2004 tentang Pembentukan Peraturan Perundang Undangan, pasal 7
} 
pancasila sebagai norma dasar (staatsfundamentalnorms) hukum di Indonesia harus dijadikan acuan utama dalam pembuatan peraturan peraturan perundang undangan. Peraturan manapun yang bertentangan dengan Pancasila dapat digugurkan demi hukum.

\section{Formalisasi Syari'at Islam di Indonesia}

Sebenarnya secara formal, Hukum Islam dalam bidang keperdataan hingga saat ini, terutama menyangkut hukum kerluarga masih tetap berlaku bagi ummat Islam sebagaimana telah dijadikan politik hukum oleh pemerintah kolonial Belanda sejak tahun 1848 sejauh pemeluk Islam ingin memberlakukan bagi diri mereka, bahkan saat ini sudah termasuk juga hukum yang terkait dengan sengketa ekonomi Islam. ${ }^{10}$

Namun saat ini, bukan hanya hukum keperdataan yang dapat diformalkan di Indonesia, hukum yang bersifat publik pun dapat juga demikian, biarpun hanya terbatas di Provinsi Nangroe Aceh Darussalam (PNAD) saja karena mendapatkan otonomi khusus melalui UU No. 18 Tahun 2001 tentang Otonomi Khusus Bagi Provinsi Daerah Istimewa Aceh. Setelah PNAD, daerah daerah lainnya juga mulai ikut menerapkan syari'at Islam sebagai hukum publik ${ }^{11}$ yang kemudian dikenal oleh masyarakat sebagai perda Syari'at.

Pasca pemberlakuan Undang Undang No. 22 tahuin 1999 tentang Pemerintahan Daerah yang membawa dampak signifikan dalam pelaksanaan pemerintahan daerah, pemerintah masih mencoba untuk melakukan perbaikan dalam pengelolaan pemerintah daerah terlebih dalam hal perimbangan keuangan antara pusat dan daerah yaitu dengan dikeluarkannya Undang Undang No. 32 tahun 2004 tentang Pemerintahan Daerah yang merupakan Undang Undang terbaru pemerintahan daerah dan masih berlaku hingga saat ini. Pemberian Otonomi inilah yang

\footnotetext{
${ }^{10}$ Pengakuan ini tertuang di dalam Kompilasi Hukum Islam (KHI) dan Kompilasi Hukum Ekonomi Islam (KHEI) serta UU No. 7 Tahun 1989 jo. UU No. 3 Tahun 2006 Tentang Peradilan Agama sebagai hukum formilnya.

${ }^{11}$ Hukum publik adalah hukum yang mengatur hubungan antara negara dengan alat alat perlengkapan atau hubungan antara negara dengan perseorangan (warga negara). Sedangkan hukum privat adalah hukum yang mengatur hubungan hubungan antara orang yang satu dengan orang yang lain, dengan menitik beratkan pada kepentingan perseorangan. C.S.T. Kansil, Pengantar Ilmu Hukum dan Tata Hukum Indonesia, Jakarta: Pn Balai Pustaka, 1989, Hlm. 75. Lihat juga L. J. Apeldoorn, Pengantar Ilmu Hukum, Jakarta: Pradnya paramita, 2000, Hlm. 171.
} 
dianggap oleh pemerintah daerah sebagai otonomi daerah seluas luasnya, sehingga banyak daerah daerah yang mengimplementasikan syari'at Islam melalui Peraturan Daerah. ${ }^{12}$

Partai Politik dan kelompok kelompok Islam yang selalu memperjuangkan formalisasi syari'at Islam ini adalah mereka yang termasuk dalam gerakan formalisasi syari'at. Sedikitnya ada tiga arus besar yang mengemuka dalam menyikapi formalisasi syari'at Islam. Pertama, arus formalisasi syari'at. Kelompok ini menghendaki agar agar syari'at Islam dijadikan landasan riil berbangsa dan bernegara. Pencantuman kembali Piagam Jakarta dalam UUD 1945 menjadi agenda utama. Kedua, arus deformalisasi syari'at. Kelompok ini memilih pemaknaan syari'at secara substansif. Pemaknaan syari'at tidak serta merta dihegemoni negara, karena wataknya yang represif. Syari'at secara individu telah diterapkan, sehingga formalisasi syari' at dalam UUD 1945 tidak memiliki alasan kuat di dalam ranah politik. Ketiga, arus moderat. Kelompok ini dikesankan mengambil jalan tengah; Menolak sekularisasi dan islamisasi, karena budaya masyarakat muslim Indonesia mempunyai kekhasan tersendiri. ${ }^{13}$

Pengaturan Peraturan Daerah Kabupaten Solok Nomor 6 Tahun 2002 tentang Berpakaian Muslim dan Muslimah di Kabupaten Solok Dalam Perspektif Hukum Ketatanegaraan Indonesia

Peraturan Daerah merupakan suatu kekuasaan yang dinisbahkan UUD 1945. Konstitusi menyatakan bahwa perda dibentuk DPRD bersama pemerintah daerah. ${ }^{14}$ Sepanjang DPRD dan pemerintah daerah sepakat atas suatu rancangan perda, rancangan tersebut akan menjadi perda. Sepanjang pengambilan keputusannya dilakukan secara demokratis dan menurut prosedur yang ada, rancangan perda yang kemudian menjadi perda harus dipandang sah, apa pun isinya. Demikian pula dengan munculnya Perda No. 6 tahun 2002 tentang Berpakaian Muslim dan Muslimah di Kabupaten Solok yang dalam proses pembuatnnya sudah melalui mekanisme yang sah sesuai dengan peraturan perundang undangan. Pemerintah Daerah dan DPRD kabupaten Solok sepakat menerapkan sebagian syari'at Islam dalam hal busana. ${ }^{15}$

\footnotetext{
${ }^{12}$ Ramli Abdul Wahid. Op. Cit

${ }^{13}$ Yusdani. "Formalisasi Syari' at Islam dan Hak Asasi Manusia di Indonesia". Dalam Al Mawarid Jurnal Hukum Islam. Edisi XVI Tahun 2006. Yogyakarta: Fakultas Ilmu Agama Islam UII. Hlm. 193.

${ }^{14}$ Pasal 18 ayat (6) UUD 1945

${ }^{15}$ Tabloid Suara Islam, Edisi 05, 01 September 2006
} 
Kabupaten Solok merupakan salah satu kabupaten di Provinsi Sumatera Barat yang mayoritas penduduknya beragama Islam. Jumlah penduduk beragama Islam di daerah ini mencapai $98 \%$, sedangkan penganut agama Kristen sebesar 1,6 \%, dan penganut agama Lain-lain hanya 0,4. ${ }^{16}$ Perda berbuasana muslim sebagaimana Perda Kabupaten Solok Nomor 6 Tahun 2002 di atas telah berlaku hampir di seluruh wilayah provinsi Sumatera Barat. Lahirnya berbagai perda bernuansa syari'at di Provinsi Sumatera Barat diawali dengan keluarnya Perda Provinsi Sumatera Barat nomor 11/2001 tentang pencegahan maksiat.

Namun, yang perlu digarisbawahi, nasib perda tidak berhenti ketika DPRD dan pemerintah daerah mengetuk palu bersama dalam suatu proses politik di daerah. Nasib perda masih akan ditentukan pada proses pengujian bila ada pihak yang berkeberatan, baik pengujian oleh pemerintah pusat (executive review) maupun oleh lembaga yudicial Mahkamah Agung (judicial review). Proses pengujian ini didasarkan pada kepentingan umum dan peraturan perundang undangan yang lebih tinggi.

Dengan demikian, maka Perda Perda No. 6 tahun 2002 tentang Berpakaian Muslim dan Muslimah di Kabupaten Solok walaupun sudah melalui proses pembuatan yang sah, tetapi harus juga dinilai menggunakan peraturan perundang undangan sesuai dengan ketentuan UU No. 10 Tahun 2004 tentang Pembentukan Peraturan Perundang Undangan.

\section{Berdasarkan Pancasila}

Sampai sekarang sudah dilakukan perubahan (amandemen) atas UUD 1945 sampai empat tahab, namun pembukaan UUD 1945 yang di dalamnya mengandung Pancasila sebagai dasar dan ideologi negara tidak ikut diamandemen. Majelis Permusyawaratan Rakyat (MPR) yang dimulai tahun 1999 mengadakan amandemen terhadap UUD 1945 berpedoman pada lima kesepakatan dasar yang salah satu di antaranya adalah tidak mengubah pembukaan UUD 1945 yang telah ditetapkan Panitia Persiapan Kemerdekaan Indonesia (PPKI) tanggal 18 Agustus 1945. Keputusan untuk tidak mengubah pembukaan UUD 1945 secara filosofis maupun politis dalam hidup bernegara bagi bangsa Indonesia sudah sangat tepat. ${ }^{17}$

\footnotetext{
${ }^{16} \mathrm{http}: / /$ www.sumbar.go.id/

${ }^{17}$ Secara filosofis, Pembukaan UUD 1945 merupakan modus vivendi (kesepakatan luhur) bangsa Indonesia untuk hidup bersama dalam ikatan satu bangsa yang majemuk. Ia
} 
Dari sudut hukum, Pembukaan UUD 1945 yang memuat Pancasila itu menjadi dasar falsafah negara yang melahirkan cita hukum (rechtside) dan dasar sistem hukum tersendiri sesuai dengan jiwa bangsa Indonesia sendiri. Pancasila sebagai dasar negara menjadi sumber dari segala sumber hukum yang memberi penuntun hukum serta mengatasi semua peraturan perundang undangan termasuk UUD $1945 .{ }^{18}$ Dalam kedudukannya yang demikian, Pembukaan UUD 1945 serta Pancasila yang dikandungnya menjadi staatfundamentalnorm atau pokok pokok kaidah negara yang fundamental dan tidak dapat dirubah dengan jalan hukum, kecuali perubahan mau dilakukan terhadap identitas aslinya yang dilahirkan pada tahun $1945 .{ }^{19}$

Dengan demikian, maka pengujian terhadap peraturan perundang undangan harus selalu didasarkan pada Pancasila terlebih dahulu, baru kemudian UUD 1945 dan seterusnya sesuai dengan yang telah diatur di dalam pasal 7 UU No. 10 tahun 2004. Sebagai dasar sistem hukum nasional, Pancasila telah memberikan pedoman hukum yang tidak boleh dilanggar. Pedoman yang paling umum adalah larangan bagi munculnya hukum yang bertentangan dengan nilai nilai Pancasila, yaitu Ketuhanan yang maha Esa, Kemanusiaan yang adil dan beradab, Persatuan Indonesia, Kerakyatan yang dipimpin oleh hikmah dalam permusyawaratan perwakilan, dan Keadilan bagi seluruh rakyat Indonesia.

Munurut Mahfud MD., substansi nilai-nilai Pancasila sebagai dasar negara meliputi:

a. Berbasis moral agama.

b. Menghargai dan melindungi hak-hak asasi manusia tanpa diskriminasi.

c. Mempersatukan seluruh unsur bangsa dengan semua ikatan primordialnya.

juga dapat disebut sebagai akta kelahiran, karena sebagai modus vivendi di dalamnya memuat proklamasi kemerdekaan serta identitas diri dan pijakan melangkah untuk mencapai cita cita bangsa dan tujuan negara. Jika Pembukaan dirubah maka Indonesia yang ada bukanlah Indonesia yang aktanya dikeluarkan pada tanggal 17 Agustus 1945, melainkan Indonesia yang lain lagi. Mahfud MD. 2007. Perdebatan Hukum tata Negara Pasca Amandemen Konstitusi. Jakarta: LP3ES. Hlm. 3.

${ }^{18}$ Sebagaimana tertuang dalam Ketetapan No.XX/MPRS/1966 jo. Ketetapan No.V/ MPR/1973 dan Ketetapan No.IX/MPR/1978. Kaelan. Tanpa tahun. Filsafat Pancasila. Yogyakarta: Paradigma. Hlm. 70.

${ }^{19}$ Mahfud MD, Op. Cit., Hlm. 4. Lihat juga Darji Darmodiharjo dkk, Santiaji Pancasila. Surabaya: Usaha Nasional.1991. , 1991, Hlm. 2. Lihat juga pasal 2 UU No. 10 tahun 2004 tentang Pembentukan Peraturan Perundang Undangan yang berbunyi "Pancasila merupakan sumber dari segala sumber hukum negara". 
d. Meletakkan kekuasaan di bawah kekuasaan rakyat.

e. Membangun keadilan sosial.

Untuk meraih cita dan mencapai tujuan dengan landasan dan panduan tersebut, maka sistem hukum nasional yang harus dibangun adalah sistem hukum Pancasila yakni sistem hukum yang mengambil atau memadukan berbagai nilai kepentingan, nilai sosial, dan konsep keadilan ke dalam satu ikatan hukum prismatik dengan mengambil unsur-unsur baiknya. ${ }^{20}$

Berdasarkan substansi sila pertama Pancasila dan pasal 29 UUD 1945, Indonesia bukanlah negara agama dan bukan pula negara sekuler. Bukan negara agama karena negara agama hanya mendasarkan pada satu agama tertentu, tetapi negara Pancasila juga bukan negara sekuler yang sama sekali tidak ikut campur dalam urusan agama. ${ }^{21}$ Negara Pancasila adalah sebuah religius nation state, yakni sebuah negara kebangsaan yang religius yang melindungi dan memfasilitasi berkembangnya semua agama yang dipeluk oleh rakyatnya tanpa membedakan besarnya pemeluk masing masing, karena pemelukan setiap orang atas satu agama merupakan salah satu hak asasi yang paling utama, maka negara tidak bisa mendasarkan diri pada satu agama, tetapi karena itu pula negara wajib membina perkembangan agama secara baik dan penuh toleransi sehingga hak asasi setiap orang untuk itu dapat terlindungi. ${ }^{22}$

Sebagai religius nation state, Pemerintah RI telah memberikan kesempatan yang luas kepada umat Islam untuk mengembangkan dan mengamalkan agamanya melalui berbagai direktorat Islam di Departemen Agama, Pengadilan Agama, Pendidikan Islam Negeri mulai dari tingkat MIN, M.Ts.N, MAN, sampai ke Perguruan Tingginya dan berbagai perundang-undangan tentang pengamalan Islam, seperti UU No. 11974 tentang Perkawinan, PP No. 9 tahun 1975 tentang Kompilasi Hukum Islam, Inpres No. 7 tahun 1992 tentang Sistem Perbankan Syariah, UU No. 17 tahun 1992 tentang Haji, UU No. 38 tahun 1999 tentang Pengelolaan Zakat. Namun semua pengaturan itu hanya untuk memfasilitasi pelaksanaan hukum agama, bukan dalam hukum publik yang bersifat represif.

${ }^{20}$ Mahfud MD, 2006, "Politik Hukum Islam dan Posisi Syari' at Islam” Dalam Makalah yang disampaikan pada Kuliah Perdana Program Pascasarjana Universitas Islam Indonesia Tahun Akademik 2006/2007 yang diselenggarakan pada tanggal 9 September 2006.

${ }^{21}$ M. Ainul Yaqin, Pendidikan Multikultural. Yogyakarta: Pilar Media, 2005, Hlm. 34-35.

${ }^{22}$ Mahfud MD, Perdebatan Hukum...Op. Cit., Hlm. 6. 
Dengan demikian, maka Peraturan Daerah Kabupaten Solok Nomor 6 tahun 2002 tentang Berbusana Muslim dan Muslimah di Kabupaten Solok tidak sesuai dengan nilai nilai Pancasila yang menghargai dan melindungi hak-hak asasi manusia tanpa diskriminasi, mempersatukan seluruh unsur bangsa dengan semua ikatan primordialnya, serta sistem hukum nasional Indonesia yang bukan berdasar agama tertentu tetapi memberi tempat kepada agama-agama yang dianut oleh rakyat untuk menjadi sumber hukum atau memberi bahan terhadap produk hukum nasional. Hukum agama sebagai sumber hukum di sini diartikan sebagai sumber hukum material (sumber bahan hukum) dan bukan harus menjadi sumber hukum formal (dalam bentuk tertentu menurut peraturan perundang-undangan). ${ }^{23}$

\section{Berdasarkan UUD 1945 dan UU No. 32 tahun 2004 Tentang Pemerintahan Daerah Dalam Kerangka Implementasi Otonomi Daerah}

UUD 1945 telah mengatur tentang pemerintahan daerah pada pasal 18 yang terdiri dari 3 pasal, yaitu pasal 18 terdiri dari 7 ayat, pasal 18A terdiri dari 2 ayat, dan pasal 18B juga terdiri atas 2 ayat. Dalam Pasal 18 ayat (5) Perubahan Kedua UUD 1945 dinyatakan: "Pemerintahan daerah menjalankan otonomi seluas-luasnya, kecuali urusan pemerintahan yang oleh undang-undang ditentukan sebagai urusan Pemerintah Pusat." Dalam ayat (6) pasal tersebut dinyatakan pula: "Pemerintahan daerah berhak menetapkan peraturan daerah dan peraturan-peraturan lain untuk melaksanakan otonomi dan tugas perbantuan".

Dengan melihat pasal pasal tersebut nampak jelas bahwa daerah memiliki wewenang yang luas untuk menjalankan otonomi daerah dan menetapkan peraturan daerah serta peraturan peraturan lainnya untuk melaksanakan otonomi daerah. Namun perlu diperhatikan juga bahwa dalam ayat (5) di atas terdapat statemen "kecuali urusan pemerintahan yang oleh undang-undang ditentukan sebagai urusan Pemerintah Pusat". Dengan demikian maka UUD 1945 menentukan bahwa dalam pelaksanaan otonomi daerah, pemerintah daerah tidak memiliki kewenangan absolut terhadap daerah, melainkan ada batasannya yang ditentukan oleh undang undang.

\footnotetext{
${ }^{23}$ Ibid., Hlm. 242.
} 
UU No. 32 tahun 2004 tentang Pemerintahan Daerah telah menentukan batasan batasan terhadap urusan urusan yang menjadi urusan pemerintah pusat, yaitu ada enam urusan absolut yang menjadi urusan pemerintah pusat, yakni hubungan luar negeri, pertahanan, keamanan, yustisi, peradilan, moneter dan fiskal nasional dan agama. ${ }^{24}$ Dengan batasan batasan tersebut tentunya para pembentuk undang undang mempunyai maksud tertentu, termasuk dalam urusan agama. Sebenarnya ketika UU No. 22 tahun 1999 sedang dibahas dalam RUU, urusan agama tidak akan dimasukkan sebagai urusan pusat, namun menjelang akhir pembahasan atas RUU tersebut, MUI dan beberapa ormas Islam serta Departemen Agama meminta agar urusan agama diserahkan ke pemerintah pusat. Tujuannya agar tidak ada daerah yang membuat peraturan daerah berdasarkan besarnya pemeluk agama masing masing karena hal itu dapat mengancam integrasi bangsa. ${ }^{25}$ Oleh karena itu, baik dalam UU No. 22 tahun 1999 maupun UU No. 32 tahun 2004, urusan agama dimasukkan sebagai urusan pemerintahan pusat.

Dimasukkannya urusan agama menjadi urusan pusat dikarenakan bangsa Indonesia terdiri dari beberapa agama yang dalam hubungan sosial kemasyarakatan sangat rawan terhadap konflik. Sangat mungkin daerah daerah tertentu akan menerapkan peraturan peraturan daerah yang didasarkan pada agama mayoritas masyarakat di suatu daerah yang menyebabkan terpinggirnya agama minorotas. Oleh karena itu, demi memberikan perlindungan terhadap semua pemeluk agama, urusan agama tetap berada pada pemerintah pusat. Kekhawatiran ini mungkin tidak akan terjadi pada daerah yang agama penduduknya heterogen dan lebih toleran, seperti Jawa. Akan tetapi di daerah daerah yang penganut agamanya hampir homogen, seperti Bali, NTT, Sulawesi Utara, Irian Jaya, maluku Utara, Sumatera Barat serta daerah daerah yang lain, pengaturan perda yang didasarkan pada agama tertentu sangat mungkin terjadi.

${ }^{24}$ Pasal 10. Bandingkan dengan Pasal 7 UU No. 22 tahun 1999. Pada pasal 7 UU No. 22 tahun 1999 menyebutkan bahwa kewenangan daerah mencakup kewenangan dalam seluruh bidang pemerintahan kecuali dalam bidang politik luar negeri, pertahanan keamanan, peradilan, peradilan, moneter dan fiskal, agama, serta kewenangan bidang lain. Kewenangan bidang lain tersebut meliputi kebijakan tentang perencanaan nasional dan pengendalian pembangunan nasional secara makro, dana perimbangan keuangan, sistem administrasi negara dan lembaga perekonomian negara pembinaan dan pemberdayaan sumber daya manusia, pendayagunaan sumber daya alam, serta tegnologi tinggi yang strategis, konservasi, dan standarisasi nasional.

${ }^{25}$ Mahfud MD, Perdebatan Hukum...Op. Cit., Hlm. 52. 
Permasalahan yang menjadi kekhawatiran dalam perumusan RUU tentang Pemerintahan Daerah sebagaimana yang telah diuraikan di atas ternyata terjadi, walaupun urusan agama sudah menjadi urusan pemerintahan pusat. Kekhawatiran yang dimaksud muncul dalam pengimplementasian perda perda yang bernuansa agama tertentu (Perda Syari'at) di daerah, di antaranya adalah Peraturan Daerah Kabupaten Solok Nomor 6 Tahun 2002 tentang Berpakaian Muslim dan Muslimah di Kabupaten Solok. Sementara Pemerintah dan DPRD Kabupaten Manokwari, Provinsi Irian Jaya Barat yang penduduknya mayoritas beragama Kristen juga sedang menggodok rancangan peraturan daerah (raperda) pembinaan mental dan spiritual berbasis Injil. ${ }^{26}$

Dengan demikian, Peraturan Daerah Kabupaten Solok Nomor 6 Tahun 2002 tentang Berpakaian Muslim dan Muslimah di Kabupaten Solok bertentangan dengan spirit pasal 18 ayat (5) UUD 1945 jo. pasal 10 UU No. 32 Tahun 2004 yang membatasi kewenangan daerah dalam urusan agama. ${ }^{27}$ Dalam UU No 32 tahun 2004 Pasal 22 secara jelas juga disebutkan bahwa dalam menyelenggarakan otonomi daerah, daerah berkewajiban menjaga persatuan, kesatuan dan keutuhan Negara Kesatuan Republik Indonesia (NKRI). Pasal 27 juga menyebutkan bahwa kepala daerah berkewajiban memegang teguh dan mengamalkan Pancasila dan UUD 1945 serta siap mempertahankan dan memelihara kedaulatan NKRI. Jika rumusan ini dipegang teguh oleh seluruh pemerintah daerah di Indonesia, maka perda perda yang bernuansa keagamaan tidak akan keluar dari jalur konstitusi, sebab dalam sebuah negara yang berdasarkan Pancasila, seluruh produk hukumnya harus mengacu dan bersumber pada Pancasila dan UUD 1945.

${ }^{26} \mathrm{http}: / /$ forum.swaramuslim.net/more.php?id=4120_0_22_0_M yang direkam pada 15 Des 2007 16:31:44 GMT.

${ }^{27}$ Latar belakang pemberian wewenang dalam urusan agama oleh pemerintah pusat yang telah diuraikan di atas dapat dijadikan tafsiran terhadap "urusan agama" dalam UU No. 32 Tahun 2004. Memahami peraturan perundang undangan dengan melihat pada sejarah hukum maupun sejarah pembentukannya disebut penafsiran (interpretasi) historis. Lihat Bambang Sutiyoso, Metode Penemuan Hukum; Upaya Mewujudkan Hukum Yang Pasti dan Berkeadilan, Yogyakarta: UII Press, 2006, Hlm. 84-85. 
Kesesuaian Peraturan Daerah Kabupaten Solok Nomor 6 Tahun 2002 tentang Berpakaian Muslim dan Muslimah di Kabupaten Solok dengan Hak Asasi Manusia

Hak Asasi Manusia (HAM) yang dalam bahasa Indonesia diartikan sebagai hak-hak mendasar pada diri manusia ${ }^{28}$ harus menjadi akar dari negara, menghormati perbedaan, menerima keanekaragaman, menerima hubungan, serta menghargai hubungan gender. Kondisi yang diperlukan adalah negara harus konsisten terhadap konstitusi, hak-hak dasar, persamaan lelaki dan perempuan, persamaan antara muslim dan nonmuslim. Inilah yang disebut peradaban. Tentu saja tidak bisa diterima alasan perbedaan untuk dijadikan alasan ketiadaan perlindungan terhadap HAM. Memang faktanya sebagian besar dari negara negara di dunia ini memiliki kebudayaan dan kondisi ekonomi yang khas, sejarah yang khas, berbeda satu sama lain, namun HAM bersifat universal bukan lokal, sehingga perlindungannya bersifat mutlak. ${ }^{29}$

Di Indonesia meskipun dalam sejarahnya ketika sidang Badan Penyelidik Usaha Persiapan Kemerdekaan (BPUPKI) terdapat perbedaan pandangan yang cukup tajam antara Soekarno, Soepomo, Moh. Yamin, dan Hatta tentang perlu dan tidaknya HAM masuk dalam UUD Indonesia nantinya, namun rancangan UUD Indonesia yang akan ditetapkan menjadi UUD resmi setelah Indonesia merdeka telah terdapat pasal pasal yang memuat perlindungan HAM. Dimasukkannya perlindungan HAM di dalam konstitusi menunjukkan bahwa founding father menyadari perlunya HAM masuk menjadi substansi konstitusi Indonesia, yaitu UUD 1945. ${ }^{30}$ Amandemen kedua UUD 1945 telah menjadi bukti akan hal itu. Pengaturan materi HAM di dalam pasal 28A sampai dengan pasal 28J UUD 1945 telah menjadi landasan konstitusional bagi perlindungan HAM di Indonesia. ${ }^{31}$

${ }^{28}$ Pius A Pratanto dan M Dahlan Al Barry, Kamus Ilmiah Populer, Surabaya: Arkola, 1994, Hlm. 48.

GMT.

${ }^{29} \mathrm{http}: / /$ apri23.multiply.com/journal/item/7 yang direkam pada 27 Nov 2007 20:46:11

${ }^{30}$ Sri Hastuti Puspita Sari. Perlindungan HAM dalam Struktur Ketatanegaraan Republik Indonesia. Dalam Eko Riyadi dan Supriyanto Abdi (ed.), Mengurai Kompleksitas Hak Asasi manusia (kajian Multi Perspektif), Yogyakarta: PUSHAM UII, 2007, Hlm. 167.

${ }^{31}$ Gregorius Sri Nurhartanto, Upaya Memerangi Diskriminasi hak Asasi Manusia. Dalam Ibid., HIm. 309. 
Memang menjalankan syari'at Islam dengan undang undang Negara sebagai alat adalah keyakinan Islam. Namun keyakinan itu hanya berlaku bagi kelompok Islam sendiri, dan itu semua terkandung di dalam hukum Islam. Sedang kan pancasilan dan UUD 1945 sebagai hukum tertinggi Negara Indonesia mengikat untuk semua warga negara. Setiap warga negara wajib taat terhadap hukum atau undang undang tersebut. Karenanya memformalisasikan syari'at Islam merupakan sesuatu yang pada prakteknya bisa melahirkan pemaksaan, intimidasi, dan kekerasan yang bertentangan dengan hak asasi manusia, pada akhirnya akan mendatangkan konflik dan bisa berakibat pada perpecahan bangsa. Syari'at Islam yang mengajarkan tentang kedamaian, kerukunan, ketentraman, kesejahteraan, dan keselamatan itu justru akan menjadi pembawa kekacauan dan penderitaan dalam segala aspek kehidupan bangsa bangsa dan masyarakat penganutnya. ${ }^{32}$

Peraturan Daerah Kabupaten Solok Nomor 6 Tahun 2002 tentang Berpakaian Muslim dan Muslimah di Kabupaten Solok merupakan Peraturan Daerah yang didasarkan pada hukum salah satu hukum agama, yaitu hukum Islam (syari'at Islam). Oleh karena itu Perda ini cenderung memicu diskriminasi terhadap kelompok minoritas, ${ }^{33}$ pasalnya mayoritas penduduk di kabupaten Solok beragama Islam.

Dalam Perda Solok ini, penerapan syari' at Islam lebih bersifat simbolis ketimbang substantif. Imbasnya, syari'at Islam bertiup pada upaya memperkecil universalitas Islam. Eksperimentasi penerapan peraturan daerah ini merupakan etalase telanjang dari simplifikasi dan pembanalan tersebut. Dari penerapan syari' at yang demikian, yang akan menjadi korban pokoknya adalah warga negara non-muslim. Mereka, warga negara nonmuslim cukup rentan terhadap ketidakadilan dan diskriminasi teologis hingga eks-komunikasi sosial. ${ }^{34}$

Dengan demikian Peraturan Daerah Kabupaten Solok Nomor 6 Tahun 2002 tentang Berpakaian Muslim dan Muslimah di Kabupaten Solok melanggar HAM yang berupa hak untuk bebas dari perlakuan diskriminatif sebagaimana yang telah diatur dalam pasal 28I ayat (2)

\footnotetext{
${ }^{32}$ Bertholomeus Bolong. "Formalisasi Syari' at Islam di Indonesia (Prespektif Gereja Katolik).” Dalam Al Mawarid Jurnal ...Op. Cit., Hlm. 156.

${ }^{33}$ http://www.freedom-institute.org/id/index.php?page=profil\&detail=artikel\&detail= dir\&id=314 yang direkam pada 7 Des 2007 23:24:40 GMT.

${ }^{34}$ Asmuni Mth. Minimbang Signifikansi Perda Syari' at (Sebuah Tinjauan Perspektif Fikih). Dalam Al Mawarid Jurnal ...Op. Cit., Hlm. 184.
} 
UUD 1945 yang disebutkan, "Setiap orang berhak bebas dari perlakuan yang bersifat diskriminatif atas dasar apapun dan berhak mendapatkan perlindungan terhadap perlakuan yang bersifat diskriminatif itu." Pasal ini mengandung arti bahwa salah satu hak asasi yang dilindungi oleh UUD 1945 adalah hak untuk mendapatkan persamaan bagi seluruh warga negara dalam segala aspek kehidupan tanpa membedakan apapun, baik itu didasarkan pada ras, agama, warna kulit, dan suku bangsa. ${ }^{35}$

Berdasarkan pasal ini, Indonesia merupakan negara netral yang tidak membedakan perbedaan ras, agama, warna kulit, maupun suku bangsa. Negara tidak membagi masyarakat beragama menjadi keluarga minoritas dan mayoritas, kesemuanya memperoleh hak yang sama. Kebebasan beragama adalah bagian yang paling penting dari hak-hak sipil. Jadi, kebebasan beragama diletakkan pada tingkat individu, sehingga tidak mengenal istilah minoritas dan mayoritas. ${ }^{36}$

Selain itu, dalam Islam banyak perbedaan paham atau penafsiran terhadap sumber hukum Islam, termasuk mengenai konsep pakaian. Konsep pakaian di dalam Islam sangat terkait dengan masalah aurat, karena bagian tubuh yang harus ditutupi adalah bagian aurat. Terkait dengan aurat laki laki secara umum ada dua pendapat di kalangan ulama'. Pertama, Madzhab Hanafi berpendapat bahwa aurat laki laki ialah bagian tubuh yang terdapat di bawah pusar sampai lutut. Sementara madzhab Syafi'i dan Hanbali juga berpendapat demikian, hanya saja menurut mereka pusar dan lutut bukan termasuk aurat. ${ }^{37}$ Kedua, Madzhab Maliki berpendapat bahwa yang di pandang sebagai aurat hanyalah penis dan dubur. ${ }^{38}$

Sementara terkait dengan aurat wanita ada sejumlah perbedaan pendapat. Pertama, Sebagian besar ulama' berpendapat bahwa aurat

${ }^{35}$ Gregorius Sri Nurhartanto, Op. Cit., Hlm. 229.

${ }^{36} \mathrm{http}$ //kompilasiriset.blogspot.com/2007/01/negara-agama-dan-penegakan-haksipil.html yang direkam pada 30 Nov 2007 07:07:09 GMT. Pasal tersebut juga selaras dengan Deklarasi Majelis Umum PBB pada tanggal 25 November 1981 lewat Resolusi Nomor GA. 36/ 55 tentang Penghapusan Semua Bentuk Keintoleransian dan Diskriminasi Berdasarkan Agama atau Kepercayaan. Dalam deklarasi itu pada dasarnya setiap orang berhak atas kebebasan berpikir, hati nurani dan agama. Dengan demikian yang terpenting adalah tidak seorang pun boleh dijadikan sasaran diskriminasi oleh negara, lembaga, kelompok, atau individu atas dasar agama atau kepercayaan.

${ }^{37}$ Abdul Azis dahlan (ed.), Ensiklopedi Hukum Islam. Jakarta: PT Ichtiar baru Van Hoeve, 2001, Hlm. 1443

${ }^{38}$ Ibid., Hlm. 144. 
perempuan adalah seluruh tubuh kecuali muka dan telapak tangan. ${ }^{39}$ Kedua, Thahir bin Ansyur, seorang ulama' besar dari Tunis memahami QS. Al Ahzab ayat 59 sebagai ajaran yang mempertimbangkan adat orang orang Arab, sehingga bangsa bangsa lain yang tidak menggunakan jilbab tidak berlaku bagi mereka ketentuan ini. Ia membolehkan bagi yang berpandangan bahwa menutup seluruh badan kecuali wajah dan telapak tangannya guna menjalankan perintah ayat tersebut. Namun dalam saat yang sama juga tidak wajar menyatakan terhadap para perempuan yang tidak memakai kerudung atau yang menampakkan tangannya bahwa mereka telah melanggar petunjuk agama, karena al Qur'an tidak pernah menyebutkan batas aurat. ${ }^{40}$ Ketiga, Nazira Zein ed Din berpendapat bahwa kehormatan seseorang bukan dinilai dari jilbab, melainkan kehormatan tersebut berakar dari hati dan merupakan asal dari kesucian, bukan berasal dari sesuatu yang bersifat simbolik, seperti jilbab. ${ }^{41}$

Karena di dalam Islam terjadi banyak penafsiran tentang masalah batasan aurat, maka Peraturan Daerah Kabupaten Solok Nomor 6 Tahun 2002 tentang Berpakaian Muslim dan Muslimah di Kabupaten Solok yang mengatur batasan berpakaian sebagaimana yang terdapat dalam pasal 7-10 perda tersebut merupakan larangan terhadap tafsir yang berbeda dengan salah satu paham agama (mainstream), sehingga perda tersebut merupakan pemaksaan terhadap paham atau penafsiran tunggal.

Baik disadari atau tidak setiap terjemahan dan tafsiran terhadap nas nas al Qur'an dan hadits nabi selalu rentan mengalami bias kepentingan, baik teologis, politis, ekonomis, sosiologis dan mungkin geografis. Hal sangat mungkin terjadi karena para ahli tafsir yang merupakan anak zamannya sangat sulit melepaskan diri sepenuhnya dari pengaruh situasi dan kondisi sosio-kultural, historis dan politis yang terjadi di sekitarnya. Kelahiran berbagai mazhab fikih, tasawuf, teologi, filsafat dan berbagai aliran politik dalam Islam menjelaskan hal itu dengan sempurna. ${ }^{42}$ Oleh karena itu, pemerintah seharusnya memberikan kebebasan kepada warganya untuk mengikuti suatu paham keagamaan tertentu yang diyakininya, bukan memaksakan terhadap suatu paham keagamaan tertentu.

${ }^{39}$ Abu bakar Jabir al Jazairi., 1424 H/2003 M. Minhajul Muslim, Beirut: Darul Fikr, Hlm. 106.

${ }^{40}$ M. Quraish Shihab, Wawasan al Qur'an, Bandung: Mizan, 2001, Hlm. 179.

${ }^{41}$ Nazira Zein ed Din, Antara Berjilbab dan Tidak, Dalam Charles Kurzman (ed.), Wacana Islam Liberal, Jakarta: Penerbit Paramadina, 2003,Hlm.135.

${ }^{42}$ Siti Musdah Mulia, Islam dan Inspirasi Kesetaraan Gender, Kibar Prss, 2007, Hlm. 231. 
Berkenaan dengan pemaksaan paham atau tafsir tunggal dalam beragama, UUD 1945 telah mengaturnya dalam pasal 28E. Pasal 28E ayat (1) yang menyatakan: "Setiap orang bebas memeluk agama dan beribadat menurut agamanya, memilih pendidikan dan pengajaran, memilih pekerjaan, memilih kewarganegaraan, memilih tempat tinggal di wilayah negara dan meninggalkannya, serta berhak kembali."

Ayat (2), "Setiap orang berhak atas kebebasan meyakini kepercayaan, menyatakan pikiran dan sikap, sesuai dengan hati nurani." Dalam pasal 29 ayat (2) juga disebutkan, "negara menjamin kemerdekaan tiap-tiap penduduk untuk memeluk agamanya masing-masing dan untuk beribadat menurut agama dan kepercayaannya itu". Berdasarkan pasal pasal ini nampak jelas bahwa kebebasan untuk memeluk agama, meyakini kepercayaan, beribadat menurut agama dan kepercayaannya merupakan Hak Asasi yang dilindungi oleh negara, bukan dipaksakan pelaksanaannya.

Kalimat "negara menjamin" yang terdapat pada pasal 29 (ayat 2) UUD 1945, bukan menjamin dalam arti pasif, tapi bersifat aktif dan imperatif. Keaktifan negara dalam menjamin kemerdekaan memeluk agama mempunyai dua sisi yaitu: Pertama, negara berkewajiban bertindak sebagai fasilitator bagi terselenggaranya peribadatan oleh kalangan pemeluk agama, sepanjang hal itu diperlukan oleh para pemeluknya, tanpa negara mencampuri otoritas dan otonomi ajaran agama. Kedua, negara berkewajiban untuk mencegah terjadinya gangguan yang datang dari luar lingkungan suatu agama, dari mana pun datangnya. ${ }^{43}$

Selain itu, walaupun Perda tentang Berpakaian Muslim dan Muslimah hanya merupakan kewajiban bagi yang beragama Islam dan merupakan anjuran bagi non-muslim, namun menurut Boniface Bakti Siregar, dari Departemen Agama mengatakan perda itu mengakibatkan dampak psikologis berat bagi siswa siswa non-muslim karena para siswa nonmuslim akan tampak berbeda dari kebanyakan teman-teman kelas mereka jika mereka tidak memakai busana Muslim, sehingga dengan terpaksa mereka memakai jilbab. ${ }^{44}$ Dengan demikian, maka Perda tentang

\footnotetext{
${ }^{43} \mathrm{http}$ ///bimasislam.depag.go.id/?mod=article\&op=detail\&klik=1\&id=141 yang direkam pada 29 Apr 2008 06:11:13 GMT.

${ }^{44} \mathrm{http}$ ://www.forum.khabar-baik.net/viewtopic.php?p=810 yang direkam pada 10 Des 2007 07:04:52 GMT. Pasal 5 Peraturan Daerah Kabupaten Solok Nomor 6 Tahun 2002 Tentang Berpakaian Muslim dan Muslimah di Kabupaten Solok berbunyi, "Setiap karyawan/ karyawati, mahasiswa/mahasiswi dan siswa/siswi Sekolah Lanjutan Tingkat Atas (SLTA) atau Madrasyah Aliyah (MA) serta pelajar Sekolah Lanjutan Tingkat Pertama (SLTP) atau
} 
Berpakaian Muslim dan Muslimah dapat memicu terjadinya pencederaan terhadap hak pemeluk agama untuk mendapatkan perlindungan negara dalam melaksanakan ajaran agamanya sesuai dengan yang diyakini.

Langkah-langkah untuk menanggulangi maraknya implementasi peraturan daerah (perda) syari'at yang tidak sesuai dengan hukum ketatanegaraan ini perlu dilakukan karena jika perda -perda bernuansa keagamaan dibiarkan terus berkembang di daerah, dapat berakibat pada terancamnya integritas NKRI. Adapun langkah langkah ini bisa berupa langkah preventif yang bersifat pencegahan maupun langkah represif yang bersifat penindakakan.

\section{Langkah Preventif}

Upaya kontrol preventif (pencegahan) yang bisa dilakukan terhadap perda adalah dengan seleksi atas semua rencana perda melalui Program Legislasi Daerah (prolegda) sesuai dengan bunyi pasal 15 ayat (2) UU No 10 tahun 2004. Dalam penjelasan pasal ini disebutkan bahwa setiap daerah harus membuat prolegda yang berisi rencana-rencana perda yang akan dikeluarkan selama satu periode (yang dapat dipenggal lagi ke dalam prolegda tahunan). Melalui pembuatan prolegda inilah, konsistensi setiap rencana perda dapat dinilai dengan peraturan perundang-undangan yang lebih tinggi, terutama dengan kaidah penuntun sistem hukum nasional.

Selain dengan langkah di atas, Perda Syari'at yang marak di Indonesia dapat juga disikapi dengan langkah politik-hukum dan sosiologi-hukum. Langkah politik-hukum dilakukan melalui pendisiplinan kebijakan partai. Suara partai di tingkat nasional maupun lokal seharusnya seragam dalam bersikap. Menjadi aneh kalau di tingkat nasional formalisasi syari'at Islam tertolak, tetapi di tingkat lokal partai yang sama justru menerima. ${ }^{45}$

Sementara secara sosiologi-hukum, pejuang syariat Islam harus lebih menoleransi jiwa kebangsaan, karena Syariat Islam tidak semakin hilang di Indonesia. Banyaknya substansi UU yang mengadopsi ide dasar hukum Islam menunjukkan syariat Islam sosial dapat diterima dalam sistem hukum nasional, dan yang lebih mengundang kontroversi adalah syariat Islam yang simbolik, syariat Islam yang terkait dengan ibadah-ritual. Arah penegakan syariat Islam lebih strategis berbingkai pada pengadopsian fikih

Madrasyah Tsanawiyah (MTSN) diwajibkan berbusana Muslim dan Muslimah, sedangkan bagi warga masyarakat umum bersifat himbauan/ anjuran".

${ }^{45}$ Gatra, Nomor 33, 29 Juni 2006 
sosial anti-korupsi, pelestarian lingkungan, demokrasi, dan sejenisnya dengan tanpa menyebut embel embel syari'at di dalamnya peraturan perundang undangannya, dibandingkan dengan mendesakkan syariat Islam permukaan-simbolik. ${ }^{46}$

\section{Langkah Represif}

PP No 20 tahun 2001 tentang Pembinaan dan Pengawasan Atas Penyelenggaraan Pemerintahan Daerah memberi kewenangan kepada Mendagri bahkan untuk membatalkan Perda yang bertentangan dengan kepentingan umum (executive review) ${ }^{47}$ Perda harus disampaikan ke pemerintah pusat paling lambat 7 (tujuh) hari setelah Perda ditetapkan untuk dikaji. Apabila setelah dikaji ternyata Perda tersebut bertentangan dengan kepentingan umum dan/ atau peraturan perundang-undangan yang lebih tinggi, maka pemerintah pusat dalam jangka waktu 60 hari setelah Perda tersebut diterima, dapat melakukan pembatalan melalui peraturan presiden. ${ }^{48}$ Dengan ini, maka pemerintah pusat hendaknya lebih aktif dalam memberikan kontrol terhadap perda. Pemerintah memang sudah banyak membatalkan perda perda yang dianggap bertentangan dengan kepentingan umum atau peraturan perundang undangan yang di atasnya, namun belum pernah ada pembatalan terhadap perda syari'at.

Selain upaya executive review di atas, upaya hukum lain yang dapat dilakukan untuk meninjau ulang Perda bisa dengan mengajukan judicial review ke Mahkamah Agung (MA). ${ }^{49}$ Namun jika suatu perda bertentangan dengan UUD 1945 berarti judicial review dapat diajukan ke Mahkamah Konstitusi (MK), karena sesuai dengan UUD 1945 pasal 24A ayat (1), MA hanya berwenang menguji peraturan perundang undangan di bawah UU terhadap peraturan perundang undangan yang diatasnya.

Sebenarnya MK juga hanya berwenang menguji UU terhadap UUD. ${ }^{50}$ Oleh karena itu, secara tertulis memang belum ada peraturan perundang undangan yang mengatur tentang judicial review terhadap perda yang

\footnotetext{
${ }^{46}$ Ibid.

${ }^{47} \mathrm{http}: / /$ www.bainfokomsumut.go.id/open.php?id=62\&db=gis yang direkam pada 8 Sep 2007 04:02:57 GMT.

${ }^{48}$ Lihat selengkapnya pada pasal 145 UU 32 tahun 2004

${ }^{49}$ Dalam UUD 1945 pasal 24A ayat (1) disebutkan bahwa wewenang Mahkamah Agung berwenang menguji peraturan perundang undangan di bawah UU terhadap peraturan perundang undangan yang diatasnya.
} 
melanggar UUD, padahal peristiwa yang demikian ini sangat mungkin terjadi. Namun dengan melihat background sejarah awal dibentuknya MK yaitu untuk mengawal konstitusi, ${ }^{51}$ maka wewenang untuk melakukan judicial review terhadap perda yang melanggar UUD. Tafsiran semacam ini disebut tafsir historis yang dikenal dalam khazanah ilmu hukum.

\section{Penutup}

Berdasarkan uraian di atas dapat disimpulkan bahwa, Perda Syari'at yang diimplementasikan di beberapa daerah dianggap tidak bersesuaian dengan hukum ketatanegaraan Indonesia dan diskriminatif, melanggar Hak Asasi Manusia.

Untuk itu,langkah-langkah untuk menanggulangi maraknya implementasi peraturan daerah (perda) syari'at yang tidak sesuai dengan hukum ketatanegaraan ini perlu dilakukan karena jika perda -perda bernuansa keagamaan dibiarkan terus berkembang di daerah, dapat berakibat pada terancamnya integritas NKRI. Adapun langkah langkah tersebut dapat berupa langkah preventif yang bersifat pencegahan maupun langkah represif yang bersifat penindakakan.

\section{Daftar Pustaka}

Abdul Azis dahlan (ed.) 2001. Ensiklopedi Hukum Islam. Jakarta: PT Ichtiar baru Van Hoeve.

Abu bakar Jabir al Jazairi. 1424 H/ 2003 M. Minhajul Muslim. Beirut: Darul Fikr.

Bambang Sutiyoso. 2006. Metode Penemuan Hukum; Upaya Mewujudkan Hukum Yang Pasti dan Berkeadilan. Yogyakarta: UII Press.

Bachsan Mustafa. 2003. Sistem Hukum Indonesia Terpadu. Bandung: PT Citra Aditya Bakti.

Charles Kurzman (ed.). 2003. Wacana Islam Liberal. Jakarta: Penerbit Paramadina.

C.S.T. Kansil. 1989. Pengantar Ilmu Hukum dan Tata Hukum Indonesia. Jakarta: Pn Balai Pustaka.

Darji Darmodiharjo dkk. 1991. Santiaji Pancasila. Surabaya: Usaha Nasional.

\footnotetext{
${ }^{50}$ Undang Undang Dasar 1945, Pasal 24C ayat (1)
}

${ }^{51}$ www.mahkamahkonstitusi.go.id. 
Gatra, Nomor 33, 29 Juni 2006

Jurnal Hukum Islam Al Mawarid. Edisi XVI Tahun 2006. Yogyakarta: Fakultas Ilmu Agama Islam UII

Kaelan. Tanpa tahun. Filsafat Pancasila. Yogyakarta: Paradigma

L. J. Apeldoorn. 2000. Pengantar Ilmu Hukum. Jakarta: Pradnya paramita. M. Ainul Yaqin. 2005. Pendidikan Multikultural. Yogyakarta: Pilar Media M. Quraish Shihab. 2001. Wawasan al Qur'an. Bandung: Mizan.

Mahfud MD. 2007. Perdebatan Hukum tata Negara Pasca Amandemen Konstitusi. Jakarta: LP3ES.

Ni'matul Huda dan Sri Hastuti Puspita Sari (ed.). 2007. Kontribusi Pemikiran untuk 50 tahun Prof. Dr. Moh Mahfud MD., SH. (Retrospeksi Terhadap Masalah Hukum dan Kenegaraan). Yogyakarta: FH UII Press.

Pius A Pratanto dan M Dahlan Al Barry. 1994. Kamus Ilmiah Populer. Surabaya: Arkola.

Ramli Abdul Wahid. Urgensi Peraturan Daerah Syariah. Dalam Waspada Online, Jumat, 02 November 2007 21:31 WIB.

Siti Musdah Mulia. 2007. Islam dan Inspirasi Kesetaraan Gender. Kibar Press. Undang Undang Dasar Negara Republik Indonesia Tahun 1945.

Undang Undang Republik Indonesia Nomor 32 Tahun 2004 tentang Pemerintahan Daerah

Peraturan Daerah Kabupaten Solok Nomor 6 Tahun 2002 Tentang Berpakaian Muslim dan Muslimah di Kabupaten Solok

Undang Undang Republik Indonesia Nomor 10 tahun 2004 tentang Pembentukan Peraturan Perundang Undangan

Undang Undang Republik Indonesia Nomor 22 tahun 1999 tentang Pemerintahan Daerah (sudah tidak berlaku)

http:/ /ayok.wordpress.com/2007/01/04/ selamatkan-indonesia-dengansyariah-menuju-indonesia-lebih-baik/ yang direkam pada 6 Des 2007 14:51:25 GMT.

http:/ / www.bainfokomsumut.go.id/open.php?id=62\&db=gis yang direkam pada 8 Sep 2007 04:02:57 GMT.

http:/ / forum.swaramuslim.net/more.php?id=4120_0_22_0_M yang direkam pada 15 Des 2007 16:31:44 GMT.

http://apri23.multiply.com/journal/item/7 yang direkam pada 27 Nov 2007 20:46:11 GMT.

h t t p : / / w w w . f r e e d o m - i n s t i t u t e.o r g / i d / index.php?page=profil\&detail=artikel\& detail=dir\&id=314 yang direkam pada 7 Des 2007 23:24:40 GMT. 
http:/ / kompilasiriset.blogspot.com/2007/01/negara-agama-danpenegakan-hak-sipil.html yang direkam pada 30 Nov 2007 07:07:09 GMT.

http:/ / www.forum.khabar-baik.net/viewtopic.php?p=810 yang direkam pada 10 Des 2007 07:04:52 GMT.

http:/ / bimasislam.depag.go.id/ ?mod=article\&op=detail\&klik=1\&id=141 yang direkam pada 29 Apr 2008 06:11:13 GMT.

http:/ / www.bainfokomsumut.go.id/open.php?id=62\&db=gis yang direkam pada 8 Sep 2007 04:02:57 GMT.

Mahfud MD. 2006. "Politik Hukum Islam dan Posisi Syari'at Islam" Dalam Makalah yang disampaikan pada Kuliah Perdana Program Pascasarjana Universitas Islam Indonesia Tahun Akademik 2006/ 2007 yang diselenggarakan pada tanggal 9 September 2006.

www.mahkamahkonstitusi.go.id.

Alamat: Gondangwayang kedu temanggung Jateng

Mahasiswa FH UII Yogyakarta 


\section{Index}

A

Abdul Azis dahlan 428

Abu bakar Jabir al Jazairi 429

Asmuni Mth 427

B

Bachsan Mustafa 416

Bambang Sutiyoso 425

Bertholomeus Bolong 427

C

C.S.T. Kansil 418

D

Dalam UU No 32 tahun 2004425

\section{E}

Eko Riyadi 426

executive review 420, 432

$\mathbf{F}$

founding father 426

G

Gregorius Sri Nurhartanto 428

Gregorius Sri Nurhartanto. 426

J

judicial review 420, 432

K

Kompilasi Hukum Islam, 422

konsensus nasional 413

L

L. J. Apeldoorn 418

lex supperiori derogat lex inferiori 417 


\section{M}

M Dahlan Al Barry 426

M. Ainul Yaqin. 422

M. Quraish Shihab. 429

Madzhab Hanafi 428

Madzhab Maliki 428

madzhab Syafi'i 428

Mahfud MD 421, 424

Mahfud MD. 422

\section{$\mathbf{N}$}

Nazira Zein ed Din 429

$\mathrm{O}$

Otomi Daerah 414

Otonomi Daerah 413

Otonomi Daerah, 416

Otonomi Khusus 418

\section{$\mathbf{P}$}

pasal 29 (ayat 2) UUD 1945, 430

Perda Syari'at 415, 416, 425, 427, 431

Pius A Pratanto 426

$\mathbf{R}$

Ramli Abdul Wahid 419

Ramli Abdul Wahid. 414

rechtside 421

religius nation state, 422

Renstra 414

\section{S}

Siti Musdah Mulia 429

Sri Hastuti Puspita Sari. 426

staatfundamentalnorm 421

staatsfundamentalnorms 418

Stufen Theory 416

Sudi fahmi. 413

Supriyanto Abdi 426

$\mathrm{U}$

Undang Undang No. 22 Tahun 1999414

UU No. 22 tahun 1999424 
UU No. 32 tahun 2004，424

$\mathbf{Y}$

Yusdani. 419 
JURNAL HUKUM NO. 3 VOL. 14 JULI 2007: 413 - 435 
JURNAL HUKUM NO. 3 VOL. 14 JULI 2007: 413 - 435 
